\title{
Mengembangkan Partisipasi Masyarakat Dalam Perlindungan dan Pengelolaan Lingkungan Hidup Untuk Pembangunan Berkelanjutan
}

\author{
Kadek Cahya Susila Wibawa \\ Fakultas Hukum, Universitas Diponegoro \\ kadekwibawa@lecturer.undip.ac.id \\ d3d3k81@gmail.com
}

\begin{abstract}
s
The research aims to find out about developing community participation in the protection and management of the environment for sustainable national development. The research method used in this study is empirical legal research that uses a conceptual approach. The results of the study show that First, the protection and management of the environment in its area is a shared responsibility, between the government (state), the private sector and the community. One of the roles of the community in environmental activities is the supervision room. Community participation in the framework of protecting the right to a good and healthy environment is accommodated in various environmental instruments, as stipulated in the PPLH Law. Secondly, empirically the involvement of the community so far in managing the new environment is solely looking at the community as the information provider (public information) or merely limited to counseling so that activities related to the environment run unimpeded. In the future, optimizing the role of the community in protecting and managing environmental activities needs to be further enhanced by opening up a wider space of participation.
\end{abstract}

Keywords: Community Participation, Environment. Sustainable Development

\begin{abstract}
Abstrak
Penelitian bertujuan untuk mengetahui mengembangkan partisipasi masyarakat dalam perlindungan dan pengelolaan lingkungan hidup untuk pembangunan nasional berkelanjutan. Metode penelitian yang digunakan dalam penelitian ini adalah penelitian hukum empiris yang menggunakan pendekatan konseptual (conceptual approach). Hasil penelitian menunjukan bahwa Pertama, Perlindungan dan pengelolaan lingkungan hidup pada dasanya merupakan tanggung jawab bersama, antara pemerintah (negara), swasta dan masyarakat. Salah satu peran masyarakat dalam aktivitas lingkungan hidup adalah ruang pengawasan. Partisipasi masyarakat dalam kerangka untuk melindungi hak atas lingkungan yang baik dan sehat, diwadahi dalam berbagai instrumen lingkungan hidup, sebagaimana diatur dalam UU PPLH. Kedua, Secara empiris pelibatan masyarakat selama ini di dalam pengelolaan lingkungan hidup baru semata-mata hanya memandang masyarakat sebagai penyampai informasi (public information) atau hanya sebatas penyuluhan sehingga suatu kegiatan yang berkaitan dengan lingkungan hidup berjalan tanpa hambatan. Kedepan, harus dilakukan optimalisasi peran serta masyarakat dalam aktivitas perlindungan dan pengelolaan lingkungan hidup perlu lebih ditingkatkan dengan membuka lebih luas ruang partisipasi.
\end{abstract}

Kata Kunci: Partisipasi Masyarakat, Lingkungan Hidup. Pembangunan Berkelanjutan 


\section{A. Pendahuluan}

Kondisi lingkungan hidup yang sehat dan baik, merupakan salah satu kebutuhan asasi bagi setiap masyarakat, khususnya masyarakat Indonesia. Kebutuhan tersebut dijamin dalam konstitusi, Pasal 28H UUDNRI 1945. ${ }^{1}$ Lebih lanjut dalam Pasal 9 ayat (3) Undang-Undang Nomor 39 Tahun 1999 Tentang Hak Asasi Manusia, menegaskan: "setiap orang berhak atas lingkungan hidup yang baik dan sehat". 2 Pengelolaan lingkungan hidup yang kurang arif dan bijaksana, akan menurunkan kualitas lingkungan hidup, demikian pula sebaliknya, pengelolaan lingkungan hidup yang dilakukan secara baik dan bijaksana, maka akan berdampak pada peningkatan kualitas lingkungan hidup. Pentingnya pengelolaan lingkungan hidup secara baik dan bijaksana adalah dalam rangka mewujudkan pembangunan yang berkelanjutan (sustainable development).

Pembangunan nasional berkelanjutan pada prinsipnya merupakan konsep pembangunan yang diselenggarakan untuk memenuhi kebutuhan generasi masa sekarang tanpa harus mengorbankan hak-hak pemenuhan kebutuhan generasai masa mendatang. ${ }^{3}$ Sehingga perlu pengelolaan dan perlindungan lingkungan hidup yang menjamin adanya keberlanjutan pembangunan untuk pemenuhan kebutuhan generasi masa mendatang. Tanggung jawab perlindungan dan pengelolaan lingkungan hidup dewasa ini bukan semata-mata menjadi tanggung jawab pemerintah atau negara saja. Pelibatan atau partisipasi masyarakat mutlak diperlukan dalam menjaga dan mengawasi lingkungan hidup agar dapat lebih baik dan lebih sehat.

Undang-Undang Nomor 32 Tahun 2009 Tentang Perlindungan dan Pengelolaan Lingkungan Hidup (UU PPLH) pada dasarnya memberikan ruang bagi pelibatan masyarakat dalam perlindungan dan pengelolaan lingkungan hidup. Pasal 26 ayat (2) UU PPLH pada prinsipnya menegaskan bahwa pelibatan masyarakat dalam perlindungan dan pengelolaan lingkungan hidup harus dilakukan berdasarkan prinsip pemberian informasi yang transparan dan lengkap serta diberitahukan sebelum kegiatan dilaksanakan. Lebih lanjut dalam Pasal 26 ayat (3) UU PPLH menyebutkan bahwa dalam memperoleh ijin lingkungan yang melibatkan masyarakat dalam bentuk aspirasi yang diusulkan oleh

\footnotetext{
${ }^{1}$ Sudi Fahmi, 2013, “Asas Tanggung Jawab Negara Sebagai Dasar Pelaksanaan Perlindungan Dan Pengelolaan Lingkungan Hidup", Jurnal Hukum, Vol. 18 No. 2 April, hlm. 2.

${ }^{2}$ Konstruksi Pasal Pasal 9 ayat (3) Undang-Undang Nomor 39 Tahun 1999 Tentang Hak Asasi Manusia (UU HAM) sama dengan konstruksi Pasal 5 ayat (1) Undang-Undang Nomor 32 Tahun 2009 Tentang Perlindungan Dan Pengelolaan Lingkungan Hidup (UU PPLH), menyebutkan: "setiap orang mempunyai hak yang sama atas lingkungan hidup yang baik dan sehat".

${ }^{3}$ I Made Arya Utama, 2007, Hukum Lingkungan Sistem Hukum Perizinan Berwawasan Lingkungan Untuk Pembangunan Daerah Berkelanjutan, Pustaka Sutra, Bandung, hlm. 26.
} 
masyrakat dibuat dalam bentuk dokumen tertulis, yang ditandatangani oleh wakil masyarakat. ${ }^{4}$

Secara yuridis, partisipasi masyarakat sangat penting dan strategis sebagai instrumen pengawas (control) dalam perlindungan dan pengelolaan lingkungan hidup, termasuk dalam pengawasan penegakan hukum bagi perbuatan-perbuatan yang dapat merusak, mencemari dan menurunkan tingkat (kualitas) lingkungan hidup. Pengintegrasian pelibatan atau partisipasi masyarakat dalam bentuk aspirasi sangat mutlak diperlukan untuk menghindari lemahnya penegakan hukum sebagai akibat kurangnya pengawasan dari masyarakat. Kegiatan pengelolaan dan perlindungan lingkungan hidup tanpa menyertakan partisipasi aspirasi masyarakat akan berdampak bahwa terbitnya ijin lingkungan dengan kondisi tersebut, semata-mata menjadi tanggung jawab pemerintah, baik secara administrasi, secara perdata maupun tanggung jawab yang timbul secara pidana.

Ketentuan pengintegrasian partisipasi masyarakat dalam bentuk aspirasi masyarakat sebagaimana yang ditegaskan dalam Pasal 26 UU PPLH sangat strategis dan berperan penting untuk digunakan mendukung pengawalan atau pengawasan pemerintah dari oknum pejabat yang akan mengeluarkan keputusan di bidang lingkungan hidup yang tidak sesuai dengan syarat-syarat dan ketentuan dalam UU PPLH atau peraturan perundang-undangan lainnya. Konsep pelibatan masyarakat akan membawa pada pengawasan yang lebih mudah apabila terjadi pelanggaran-pelanggaran di bidang lingkungan hidup dan akan mudah di dalam penerapan sangsi sesuai tingkat kesalahannya. ${ }^{5}$

Pada tahap penerapan dari ketentuan Pasal 26 UU PPLH dengan memberi ketentuan tentang peran serta dan tanggapan masyarakat terhadap suatu rencana usaha dan/atau kegiatan, sehingga penerapan ketentuan pasal tersebut dapat lebih efektif. Kepastian penerapan hukum lingkungan sangat sulit diselesaikan mengingat kelemahankelemahan penormaan dalam UU PPLH, maka dalam upaya memaksimalkan perlindungan dan pengelolaan lingkungan hidup serta penegakan hukum sudah seharusnya didukung dengan pelibatan masyarakat secara aktif dan maksimal. Pemerintah (negara) wajib memeberikan ruang bagi masyarakat untuk berpartisipasi

\footnotetext{
${ }^{4}$ Masyarakat yang dimaksud adalah masyarakat yang terkena dampak, pemerhati lingkungam hidup dan/atau yang terpengaruh atas segala bentuk keputusan proses amdal. Hal tersebut diatur dalam Pasal 26 ayat (4) UU PPLH.

${ }^{5}$ Imam Supardi, 2003, Lingkungan Hidup dan Kelestariannya, Alumni, Bandung, hlm. 35.
} 
dalam pengelolaan lingkungan hidup untuk mewujudkan pembangunan nasional yang berkelanjutan.

Secara khusus Pasal 70 UU PPLH mengatur dengan jelas peran serta masyarakat dalam aktivitas yang berkaitan dengan perlindungan dan pengelolaan lingkungan hidup. Pasal 70 ayat (1) UU PPLH menyatakan bahwa: masyarakat memiliki hak dan kesempatan yang sama dan seluas-luasnya untuk berperan aktif dalam perlindungan dan pengelolaan lingkungan hidup. Peran masyarakat sebagaimana yang dimaksud dalam Pasal 70 ayat (1) UU PPLH, dapat berupa:

a. Pengawasan sosial.

b. Pemberian saran, pendapat, usul, keberatan, pengaduan.

c. Penyampaian informasi dan/atau laporan.

Mendasarkan uraian tersebut, maka tulisan ini mengambil judul "Mengembangkan Ruang Partisipasi Masyarakat dalam Perlindungan dan Pengelolaan Lingkungan Hidup untuk Pembangunan Nasional Berkelanjutan", dengan titik tolak kajian akan membahas partisipasi masyarakat dalam perlindungan dan pengelolaan lingkungan hidup dilihat dari aspek pengawasan; makna dan relevansi partisipasi masyarakat dalam perlindungan dan pengelolaan lingkungan hidup untuk mewujudkan pembangunan nasional berkelanjutan.

\section{B. Pembahasan}

\section{Partisipasi Masyarakat dalam Perlindungan dan Pengelolaan Lingkungan Hidup Dilihat dari Aspek Pengawasan}

Perlindungan dan pengelolaan lingkungan hidup pada dasanya merupakan tanggung jawab bersama, antara pemerintah (negara), swasta dan masyarakat. Pengelolaan lingkungan hidup yang didasarkan pada prinsip-prinsip tata kelola yang baik (good governance), akan menghindari atau mengurangi konflik di bidang lingkungan hidup. The UN Development Program (UNDP) pada tahun 1997 mengemukakan 8 (delapan) prinsip good governance yakni : kesetaraan untuk berpartisipasi dalam pembuatan kebijakan, ketanggapan atas kebutuhan stakeholder (responsiveness), kemampuan untuk memediasi perbedaan diantara stakeholder untuk mencapai consensus bersama, akuntabilitas kepada stakeholder yang dilayani, transparansi dalam proses pengambilan kebijakan,aktivitas didasarkan pada aturan/kerangka hukum, memiliki visi yang luas dan jangka panjang untuk memperbaiki proses tata kelola yang menjamin keberlanjutan pembangunan sosial dan ekonomi, serta jaminan atas hak semua orang 
untuk meningkatkan taraf hidup melalui cara-cara yang adil dan inklusif. Konsep serupa juga terdapat dalam Undang-Undang Nomor 28 Tahun 1998 Tentang Penyelenggaraan Negara yang Bersih dan Bebas dari Korupsi, Kolusi, dan Nepotisme mengenai asas-asas umum pemerintahan negara yang baik, yakni: asas kepastian hukum, asas tertib penyelenggaraan negara, asas kepentingan umum, asas keterbukaan, asas proporsionalitas, asas profesionalitas, dan asas akuntabilitas.

Wahana Lingkungan Hidup Indonesia (Walhi) merilis data konflik di bidang lingkungan hidup dalam laporannya setiap tahun, sebagaimana tergambar pada diagram berikut:

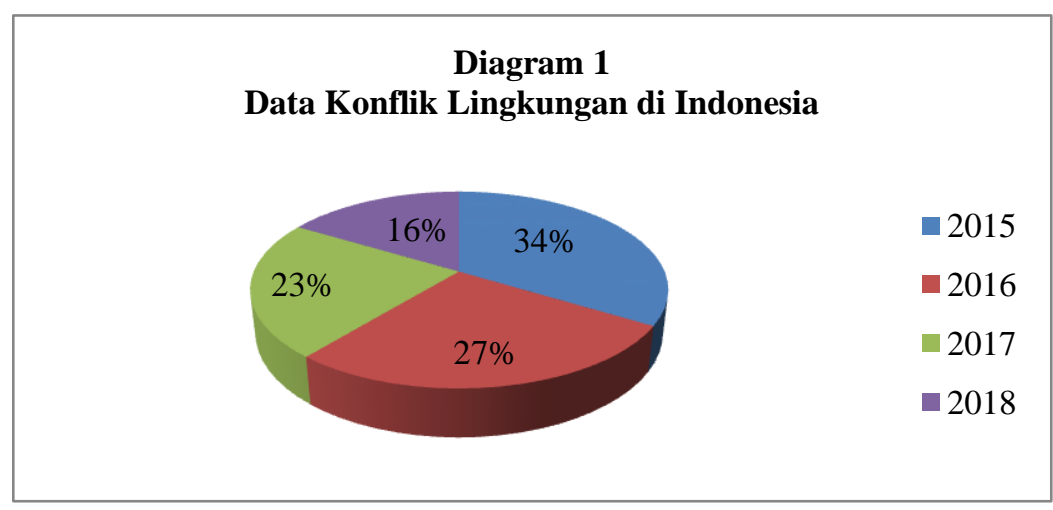

Sumber: Laporan “Tinjauan Lingkungan Hidup Walhi”

Pada durasi tahun 2015 sampai dengan 2018, tercatat terjadi 1339 konflik di bidang lingkungan, dengan rincian: tahun 2015 (451 kasus), 2016 (366 konflik), 2017 (302 konflik), dan 2018 (220 konflik). Penurunan konflik di bidang lingkungan hidup, terjadi karena mulai dioptimalkannya peran serta masyarakat di dalam aktivitas yang berkaitan dengan lingkungan hidup.

Salah satu peran masyarakat dalam aktivitas lingkungan hidup adalah ruang pengawasan. Pengawasan merupakan partisipasi masyarakat sebagai bagian dari ruang lingkup penegakan hukum administrasi yang bersifat preventif, karena pengawasan merupakan langkah preventif memaksakan kepatuhan. ${ }^{6}$ Pengawasan merupakan bagian dari tindakan pemerintah untuk mencegah terjadinya pelanggaran terhadap ketentuanketentuan yang berlaku. Pemerintah dalam menjalankan fungsi pengawasan di bidang lingkungan hidup, wajib mengoptimalkan pelibatan masyarakat untuk mencapai

${ }^{6}$ Imam Supardi, Op.cit., hlm. 23. 
optimalisasi pengawasan, sehingga pengawasan akan menjadi lebih efektif, efisien dan optimal.

Penggerakan masyarakat dalam pengawasan terhadap aktivitas lingkungan hidup harus sampai ke tingkat daerah atau satuan wilayah yang terbawah. Pengawasan merupakan syarat bagi pemerintah di dalam pengenaan sanksi administrasi bagi pelanggar yang melakukan pelanggaran di bidang lingkungan hidup. Bahwa pemerintah menunjukan pengawasan atau pemantauan tersebut dalam rangka keseriusan untuk menegakan peraturan perundang-undangan di bidang lingkungan hidup. Di samping itu, pengawasan yang melibatkan masyarakat bertujuan untuk membina penanggung jawab usaha dan. Atau kegiatan sebagai pelaksanaan asas kecermatan sebelum penerapan sanksi administrasi di bidang lingkungan hidup diberlakukan. ${ }^{7}$

Partisipasi masyarakat dalam kerangka untuk melindungi hak atas lingkungan yang baik dan sehat, diwadahi dalam berbagai instrumen lingkungan hidup. Instrumen lingkungan hidup tersebut berfungsi sebagai sarana pencegahan pencemaran lingkungan akibat pengelolaan lingkungan, meliputi: perencanaan, pengawasan, baku mutu lingkungan (BML), analisis mengenai dampak lingkungan (AMDAL), PKL-UPL, perijinan lingkungan, instrumen ekonomik dan audit lingkungan. Lebih lanjut dalam Pasal 26 UU PPLH yang mengatur pelibatan partisipasi masyarakat dalam dokumen AMDAL, meliputi: pengkajian, evaluasi, saran masukan, serta tanggapan terhadap dampak lingkungan hidup.

Hukum merupakan salah instrumen lingkungan hidup yang berfungsi untuk pencegahan kerusakan lingkungan. Instrumen hukum yang diperlukan dalam bidang lingkungan hidup, yaitu hukum yang mampu memiliki ketanggapan sosial, kepekaan terhadap kebijaksanaan negara yang dijadikan dasar bagi pemenuhan kebutuhankebutuhan dasar manusia. Masyarakat memiliki hak dan kesempatan yang sama dan seluas-luasnya untuk berperan aktif dalam perlindungan dan pengelolaan lingkungan dalam kerangka instrumen hukum tersebut. Masyarakat berhak mengajukan gugatan perwakilan kelompok untuk kepentingan diri sendiri dan/atau untuk kepentingan masyarakat apabila mengalami kerugian sebagai akibat pencemaran dan/atau kerusakan lingkungan hidup (Pasal 91 UU PPLH).

\footnotetext{
${ }^{7}$ Joko Soebagyo, 1999, Hukum Lingkungan, Masalah dan Penanggulangan (Cetakan II), Rineka Cipta, Jakarta, hlm. 47.
} 
Lingkungan hidup merupakan persoalan kolektif yang membutuhkan partisipasi semua komponen bangsa untuk mengurus dan mengelolanya. ${ }^{8}$ Pemerintah, tokoh-tokoh masyarakat, semua warga masyarakat lembaga swadaya masyarakat (LSM) harus memiliki political will yang kuat untuk secara kolegia menjaga kelestarian lingkungan hidup untuk menjamin pemenuhan hak atas kebutuhan generasi mendatang (sustainable development). Untuk itu perlu adanya pengawasan yang ketat, dan berkesinambungan dari berbagai pihak, termasuk di dalamnya masyarakat terhadap setiap proses pembuatan dan penegakan hukum yang berkaitan dengan aktivitas di dalam bidang lingkungan hidup. Pengawasan sosial yang dilakukan masyarakat dan lembaga swadaya masyarakat harus dibarengin dengan penegakan atau tindakan hukum yang tegas terhadap pelakupelaku kejahatan lingkungan hidup yang senyata-nyata telah terbukti merusak lingkungan hidup dan menyeng sarakan umat manusia.

Setiap individu merupakan bagian dari masyarakat yang memiliki hak, kewajiban dan peran yang sama dalam perlindungan dan pengelolaan lingkungan hidup, tanpa terkecuali. Keberadaan masyarakat akan efektif dan optimal di dalam melakukan pengawasan terhadap aktivitas perlindungan dan pengelolaan lingkungan hidup. Menurut Koesnadi Hardjasoemantri mengatakan bahwa "peran serta masyarakat dalam perlindungan dan pengelolaan lingkungan hidup memiliki jangkauan yang sangat luas".9 Peran serta tersebut tidak hanya meliputi peran serta setiap individu yang terkena dampak dari berbagai peraturan atau keputusan administratif, akan tetapi meliputi pula peran serta kelompok dan/atau organisasi dalam masyarakat. Partisipasi masyarakat secara efektif akan dapat melampaui kemampuan orang-seorang, sehingga peran serta kelompok dan organisasi sangat diperlukan, terutama yang bergerak di bidang lingkungan hidup. ${ }^{10}$

Aspirasi masyarakat sebagai bentuk pengawasan terasa penting dalam mekanisme atau prosedur administrasi perlindungan dan pengelolaan lingkungan hidup, seperti misalnya dalam hal perijinan, aspirasi dalam analisis mengenai dampak lingkungan (AMDAL), dan sebagainya. Namun demikian, dewasa ini masih terdapat kekhawatiran terhadap asas keterbukaan dan peran serta masyarakat dalam pengelolaan lingkungan hidup tidak terlaksana secara maksimal. Padahal secara yuridis, Pasal 70 ayat

\footnotetext{
${ }^{8}$ Siti Sundari Rangkuti, 2003, Instrumen Hukum Pengelolaan Lingkungan Hidup, Seminar Pemikiran Perubahan Undang-Undang Nomor 23 Tahun 1997 Tentang Pengelolaan Lingkungan Hidup, Jakarta, hlm. 19.

${ }^{9}$ Koesnadi Hardjasoemantri, 2005, Hukum Tata Lingkungan, Gadjah Mada University Press, Yogyakarta, hlm.83.

${ }^{10}$ Koesnadi Hardjasoemantri, ibid.,hlm.97
} 
(1) UU PPLH menyatakan bahwa masyarakat memiliki hak dan kesempatan yang sama dan seluas-luasnya untuk berperan aktif dalam perlindungan dan pengelolaan lingkungan hidup. Lebih lanjut dalam Pasal 70 ayat (2) UU PPLH dengan tegas menyatakan peran serta masyarakat dalam perlindungan dan pengelolaan lingkungan hidup dapat berupa: pengawasan sosial; pemberian saran, pendapat, usul, keberatan, pengaduan; penyampaian informasi dan/atau laporan.

Pasal 70 ayat (3) huruf d UU PPLH menyebutkan bahwa salah satu peran masyarakat dalam perlindungan dan pengelolaan lingkungan hidup di lakukan dengan pengawasan sosial. Aspek pengawasan sosial di Indonesia yang mengandung sistem demokrasi perwakilan, maka masyarakat dapat menyampaikan aspirasinya melalui keterwakilan masyarakat dalam lembaga parlemen, seperti; Dewan Perwakilan Rakyat Daerah (DPRD), baik tingkat kabupaten atau kota maupun DPRD Provinsi; Dewan Perwakilan Rakyat (DPR); dan Dewan Perwakilan Daerah (DPD). Pelibatan masyarakat melalui lembaga parlemen lebih mengarah pada fungsi legislasi atau pengaturan, dimana masyarakat ikut melakukan pengawasan terhadap pembuatan undang-undang atau peraturan undang-undang lainnya yang berkenaan dengan lingkungan hidup.

Selain aspek pengawasan sosial, pelibatan masyarakat dapat pula berupa pemberian saran, pendapat, usul, keberatan, dan/atau pengaduan. Keberatan terhadap tindakan-tindakan yang dapat merusak atau menurunkan kualitas lingkungan hidup dapat dilakukan dengan mengajukan keberatan kepada pihak yang berwenang atau lembaga negara yang mengurusi bidang pengelolaan lingkungan hidup. Penyampaian pengaduan atau laporan dapat dilakukan oleh masyarakat kepada lembaga penegak hukum atau instansi yang berwenang, apabila menemukan tindakan-tindakan yang merusak lingkungan hidup. Apabila dikemudian hari menimbulkan sengketa di antara masyarakat yang keberatan melakukan pengaduan, maka penyelesaian sengketa lingkungan hidup dapat ditempuh melalui pengadilan (litigasi) atau di luar pengadilan (non litigasi). Pilihan penyelesaian sengketa lingkungan hidup di lakukan secara sukarela oleh para pihak yang bersengketa. $^{11}$ Sedangkan untuk aspek penyampaian informasi dan/atau laporan masyarakat dapat segera menyampaikannya kepada pemerintah atau organisasi

\footnotetext{
${ }^{11}$ Jimly Asshiddiqie, 2012, Hukum Tata Negara dan Pilar-Pilar Demokrasi, Sinar Grafika, Jakarta, hlm. 54.
} 
lingkungan hidup, sehingga apabila terjadi permasalahan segera dapat diupayakan perbaikan dan pencegahan kerusakan lingkungan hidup yang lebih parah. ${ }^{12}$

UU PPLH sangat menegaskan tentang perlunya partisipasi masyarakat dalam perlindungan dan pengelolaan lingkungan hidup, sehingga pemerintah (negara) mempunyai kewajiban untuk meningkatkan keperdulian masyarakat dalam bidang lingkungan hidup. Hampir setiap hari media koran, media televisi, media sosial, dan media informasi lainnya menginformasikan berita atau informasi mengenai bencana ekologi, seperti banjir, kekeringan, abrasi, kebakaran hutan dan lahan, dan lain sebagainya. Menurut data Badan Nasional Penanggulangan Bencana (BNPB) menyebutkan bahwa pada tahun 2018 tercatat 2197 kejadian bencana alam (bencana ekologi) yang terjadi di Indonesia dan kejadian bencana alam ini meningkat dari tahun sebelumnya, yaitu 1954 kejadian bencana alam yang tercatat pada tahun 2017. Berikut data bencana ekologi di Indonesia dari tahun 2015-2014:

Tabel 1. Data Bencana Ekologi di Indonesia

\begin{tabular}{|lcccc|}
\hline Jenis Bencana Ekologi & $\mathbf{2 0 1 5}$ & $\mathbf{2 0 1 6}$ & $\mathbf{2 0 1 7}$ & $\mathbf{2 0 1 8}$ \\
\hline Banjir & 525 & 824 & 980 & 871 \\
\hline Tanah Longsor & 502 & 599 & 848 & 614 \\
\hline Abrasi & 7 & 22 & 11 & 53 \\
\hline Kekeringan & 7 & 0 & 19 & 130 \\
\hline Kebakaran Hutan \& Lahan & 46 & 178 & 96 & 522 \\
\hline Total & 1087 & 1623 & 1954 & 2197 \\
\hline
\end{tabular}

Sumber: www.bnpb.cloud/dibi

Mendasarkan pada data tersebut, maka terjadi kenaikan kejadian bencana alam (bencana ekologi) di Indonesia dalam kurun 4 tahun terakhir. Oleh karena itu perlu kerja sama yang berkesinambungan di antara para stakeholder dengan masyarakat di dalam mengantisipasi kerusakan lingkungan yang lebih parah.

\section{Makna dan Relevansi Partisipasi Masyarakat Dalam Perlindungan dan Pengelolan Lingkungan Hidup untuk Mewujudkan Pembangunan Nasional Berkelanjutan}

Berdasarkan Pasal 2 huruf k UU PPLH ditegaskan bahwa perlindungan dan pengelolaan lingkungan hidup dilaksanakan dengan mendasarkan pada asas partisipatif. Berbagai faktor dapat mempengaruhi perlibatan masyarakat di dalam

\footnotetext{
${ }^{12}$ Ibid., hlm. 55.
} 
perlindungan dan pengelolaan lingkungan hidup. Faktor-faktor tersebut dapat bersumber dari internal, antara lain: kemauan atau keinginan masyarakat serta kemampuan untuk terlibat dalam perlindungan dan pengelolaan lingkungan hidup; maupun faktor eksteral, antara lain : ruang yang disediakan oleh undang-undang, peran aparat lembaga formal dan nonformal yang membantu masyarakat untuk berpartisipasi dalam aktivitas perlindungan dan pengelolaan lingkungan hidup.

Makna partisipasi masyarakat pengelolaan lingkungan hidup, termasuk di dalamnya aktivitas pencegahan, penanggulangan kerusakan dan pencemaran serta pemulihan kualitas lingkungan telah menuntut dikembangkannya berbagai perangkap kebijakan dan program serta kegiatan yang didukung oleh sistem pendukung pengelolaan lingkunga lainnya. ${ }^{13}$ Peran serta masyarakat, pada dasarnya merupakan proses yang melibatkan masyarakat umum atau proses komunikasi dua arah yang berlangsung terus-menerus untuk meningkatkan pengertian masyarakat secara penuh dan holistik atas suatu proses kegiatan mengenai masalah dan kebutuhan lingkungan hidup.

Pemahaman dan pengertian peran serta masyarakat dalam perlindungan dan pengelolaan lingkungan hidup sangatlah luas, sehingga menimbulkan berbagai penafsiran atau interpretasi yang seringkali mereduksi peran serta dari masyarakat. ${ }^{14}$ Secara empiris pelibatan masyarakat selama ini di dalam pengelolaan lingkungan hidup baru semata-mata hanya memandang masyarakat sebagai penyampai informasi (public information) atau hanya sebatas penyuluhan sehingga suatu kegiatan yang berkaitan dengan lingkungan hidup berjalan tanpa hambatan. Konsep ini hanya memandang peran serta masyarakat sebagai sarana atau alat untuk mencapai suatu tujuan. Padahal, secara yuridis pelibatan masyarakat dalam kegiatan perlindungan dan pengelolaan lingkungan hidup bukan semata-mata sebagai alat untuk mencapai tujuan, tetapi juga digunakan sebagai tujuan. ${ }^{15}$

UU PPLH mengembangkan konsep peran serta masyarakat dengan pola hubungan konsultatif dan pola hubungan kemitraan. Pola hubungan konsultatif menitikberatkan pada kelompok masyarakat yang berkepentingan mempunyai hak untuk didengar aspirasinya dan untuk diberitahu oleh pihak pengambil keputusan,

\footnotetext{
${ }^{13}$ Sudharto P. Hadi, 1996, Pembangunan Berkelanjutan di Era Globalisasi, Akademika, Surakarta, hlm. 63. ${ }^{14}$ Rohmijati, 2010, Kearifan Lingkungan Menuju Hidup Sehat, Waspada, Yogyakarta, hlm.35. ${ }^{15}$ Sudharto P.Hadi, Op.cit., hlm.67.
} 
meskipun keputusan terakhir tetap berada di tangan pembuat keputusan tersebut. Pelibatan masyarakat dalam konteks kemitraan menurut UU PPLH, bermakna bahwa pembuat keputusan dan anggota masyarakat merupakan mitra yang sejajar kedudukannya. Para pihak membahas masalah secara bersama-sama, mencari berbagai alternatif pemecahan masalah dan membahas keputusan. Kedua pola hubungan tesebut akan menempatkan aspirasi masyarakat sebagai informasi yang berharga bagi para pengambil keputusan serta akan mereduksi kemungkinan terjadinya penolakan masyarakat untuk menerima keputusan tersebut. Pemberian akses atau informasi tentang pengelolaan lingkungan hidup merupakan bagian yang tidak terpisahkan dari aspek peran serta masyarakat dalam aktivitas pengelolaan lingkungan hidup.

Partisipasi masyarakat sangat efektif dalam mencegah terjadinya kerusakan lingkungan hidup, sehingga apabila terdapat permasalahan dapat diupayakan perbaikan dan pencegahan kerusakan lingkungan hidup yang lebih parah. ${ }^{16}$ Terdapat beberapa kendala yang muncul dari masyarakat indonesia dalam kaitannya dengan partisipasi masyarakat dalam lingkungan hidup, antara lain: ${ }^{17} 1$. Moral masyarakat. Sebagian besar masyarakat menganggap bahwa sumber daya alam diciptakan oleh Tuhan untuk manusia, sehingga manusia berhak untuk mengeksploitasinya. 2.

Budaya masyarakat. Karakter budaya masyarakat Indonesia yang cenderung menghindari konflik dan kesepakatan dimana ekspresi langsung ketidak setujuan terutama dengan gagasan atau rencana pihak yang lebih tinggi tidak pernah terjadi. Ada anggapan tabu apabila masyarakat melakukan kritik langsung kepada pihak yang lebih tinggi. 3. Pendidikan masyarakat. Tingkat pendidikan yang masih rendah mengakibatkan pengertian dan pemahaman mengenai lingkungan hidup pun masih rendah. 4. Tingkat ekonomi masyarakat. Indonesia termasuk negara berkembang dengan penghasilan yang masih rendah, sehingga eksploitasi masyarakat yang sebesar-besarnya terhadap lingkungan adalah untuk memenuhi kebutuhannya. 5.

Tingkat penguasaan teknologi. Masih terbatasnya penguasaan teknologi oleh masyarakat untuk pengelolaan lingkungan hidup, serta teknologi yang berbiaya mahal untuk pengelolaan lingkungan hidup.

\footnotetext{
${ }^{16} \mathrm{Ibid} ;$ hlm 68.

${ }^{17}$ Rachmadi Usman, 2003, Pembaharuan Hukum Lingkungan Nasional, PT Citra Aditya Bakti, Bandung, hlm. 113.
} 
Lingkungan hidup yang baik dan hebat serta berkelanjutan terjalin suatu interaksi yang harmonis dan seimbang antar komponen-komponen lingkungan hidup. Usaha manusia mempengaruhi stabilitas keseimbangan dan keserasian interaksi antar komponen lingkungan hidup tersebut. Hal tersebut karena manusia merupakan komponen lingkungan hidup yang paling dominan dalam mempengaruhi lingkungan. Pasal 14 UU PPLH memuat 13 instrumen pencegahan pencemaran dan/atau kerusakan lingkungan hidup yang menjadi dasar peran serta masyarakat dalam pengelolaan lingkungan hidup. Pemerintah (negara) wajib memastikan tejadinya integrasi prinsip pembangunan berkelanjutan (sustainable development) dalam pembangunan suatu wilayah, sebagaimana ketentuan dalam Pasal 15 ayat (1) UU PPLH.

Dalam rangka mewujudkan tujuan pembangunan nasional berkelanjutan, maka berdasarkan Pasal 70 UU PPLH adalah dengan mengoptimalkan peran serta masyarakat dalam perlindungan dan pengelolaan lingkungan hidup. Peran serta masyarakat dalam aktivitas perlindungan dan pengelolaan lingkungan hidup dilakukan dengan tujuan untuk: a. Meningkatkan kepedulian dalam perlindungan dan pengelolaan lingkungan hidup. b.Meningkatkan kemandirian, keberdayaan masyarakat, dan kemitraan. c.Menumbuhkembangkan kemampuan dan kepeloporan masyarakat. d.Menumbuhkembangkan ketanggapsegeraan masyarakat untuk melakukan pengawasan sosial. e. Mengembangkan dan menjaga budaya dan kearifan lokal dalam rangka pelestarian fungsi lingkungan hidup.

Apabila optimalisasi pelibatan masyarakat dalam perlindungan dan pengelolaan lingkungan dapat dilaksanakan dengan baik oleh pemerintah, maka niscaya pembangunan nasional berkelanjutan (national sustainable development) akan dapat terwujud, demi pemenuhan hak atas kebutuhan generasi yang akan datang.

\section{Simpulan}

Mendasarkan uraian pembahasan pada bab sebelumnya, maka dapat disampaikan beberapa kesimpulan, yaitu: Pertama, Perlindungan dan pengelolaan lingkungan hidup pada dasanya merupakan tanggung jawab bersama, antara pemerintah (negara), swasta dan masyarakat. Salah satu peran masyarakat dalam aktivitas lingkungan hidup adalah ruang pengawasan. Partisipasi masyarakat dalam kerangka untuk melindungi hak atas lingkungan yang baik dan sehat, diwadahi dalam berbagai instrumen lingkungan hidup, sebagaimana diatur dalam UU PPLH. UU 
PPLH sangat menegaskan tentang perlunya partisipasi masyarakat dalam perlindungan dan pengelolaan lingkungan hidup, sehingga pemerintah (negara) mempunyai kewajiban untuk meningkatkan keperdulian masyarakat dalam bidang lingkungan hidup.

Kedua, Secara empiris pelibatan masyarakat selama ini di dalam pengelolaan lingkungan hidup baru semata-mata hanya memandang masyarakat sebagai penyampai informasi (public information) atau hanya sebatas penyuluhan sehingga suatu kegiatan yang berkaitan dengan lingkungan hidup berjalan tanpa hambatan. UU PPLH mengembangkan konsep peran serta masyarakat dengan pola hubungan konsultatif dan pola hubungan kemitraan. Partisipasi masyarakat sangat efektif dalam mencegah terjadinya kerusakan lingkungan hidup, sehingga apabila terdapat permasalahan dapat diupayakan perbaikan dan pencegahan kerusakan lingkungan hidup yang lebih parah. Optimalisasi pelibatan masyarakat dalam perlindungan dan pengelolaan lingkungan hidup, maka akan mendukung pelaksanaan pembangunan nasional berkelanjutan (national sustainable development).

Terkait dengan pembahasan serta rumusan kesimpulan yang telah diuraikan, maka beberapa saran atau rekomendasi yang relevan untuk direalisasikan oleh pemerintah, lembaga-lembaga yang terkait, maupun masyarakat sebagai partisipan dalam aktivitas perlindungan dan pengelolaan lingkungan hiudp, antara lain: 1. Optimalisasi peran serta masyarakat dalam aktivitas perlindungan dan pengelolaan lingkungan hidup perlu lebih ditingkatkan dengan membuka lebih luas ruang partisipasi tersebut. 2. Ruang aspirasi masyarakat harus ditaati oleh pelaku atau pihak-pihak yang akan melakukan kegiatan yang bersinggungan dengan lingkungan hidup. 3.Pemerintah dan lembaga legislatif dapat membuat instrumen hukum khusus, yang berkaitan dengan pelibatan masyarakat dan penyampaian aspirasi berkenaan dengan pengelolaan lingkungan hidup.

\section{Daftar Pustaka}

Arya Utama I Made, 2007, Hukum Lingkungan Sistem Hukum Perizinan Berwawasan Lingkungan Untuk Pembangunan Daerah Berkelanjutan, Pustaka Sutra, Bandung.

Arya Utama I Made, 2008, "Pembangunan Berkelanjutan Dalam Kerangka Otonomi Daerah", Jurnal Konstitusi Vol. I No. 1 PKK-FH Universitas Udayana. 
Asshiddiqie Jimly, 2012, Hukum Tata Negara dan Pilar-Pilar Demokrasi, Sinar Grafika, Jakarta.

Dyah Adriantini Sintha Dewi, 2012, "Konsep Pengelolaan Lingkungan Hidup, Menuju Kemakmuran Masyarakat", Jurnal Fakultas Hukum Universitas Muhammadiyah Malang Vol I No. 1.

Fahmi Sudi, 2013, "Asas Tanggung Jawab Negara Sebagai Dasar Pelaksanaan Perlindungan Dan Pengelolaan Lingkungan Hidup", Jurnal Hukum, Vol. 18 No. 2

Hadi Sudharto P., 1996, Pembangunan Berkelanjutan di Era Globalisasi, Akademika, Surakarta.

Hardjasoemantri Koesnadi, 2005, Hukum Tata Lingkungan, Gadjah Mada University Press, Yogyakarta.

Hetifah Sj Sumarto, 2008, Membangun Partisipasi Warga dalam Tata Pemerintahan di

Indonesia: Praktek, Kebijakan, dan Agend, Local Government Support Program, Civil Society Strengthening Team, Jakarta.

IDS, 2001, Learning Initiative on Citizen Participation and Local Governance, IDS, Jakarta.

Luwihono, Slamet (ed.), 2006, Perencanaan dan Penganggaran Partisipatif untuk Good Governance, FPPM, Bandung.

Rohmijati, 2010, Kearifan Lingkungan Menuju Hidup Sehat, Waspada, Yogyakarta.

Soebagyo Joko, 1999, Hukum Lingkungan, Masalah dan Penanggulangan (Cetakan II), Rineka Cipta, Jakarta.

Sumarto, Hetifah Sj, 2003, Inovasi, Partisipasi dan Good Governance, Yayasan Obor Indonesia, Jakarta.

Sundari Rangkuti Siti, 2003, Instrumen Hukum Pengelolaan Lingkungan Hidup, Seminar Pemikiran Perubahan Undang-Undang Nomor 23 Tahun 1997 Tentang Pengelolaan Lingkungan Hidup, Jakarta.

Supardi Imam, 2003, Lingkungan Hidup dan Kelestariannya, Alumni, Bandung.

Undang-Undang Dasar Negara Republik Indonesia 1945.

Undang-Undang Nomor 28 Tahun 1998 Tentang Penyelenggaraan Negara yang Bersih dan Bebas dari Korupsi, Kolusi, dan Nepotisme.

Undang-Undang Nomor 32 Tahun 2009 Tentang Perlindungan Dan Pengelolaan Lingkungan Hidup

Undang-Undang Nomor 39 Tahun 1999 Tentang Hak Asasi Manusia.

Usman Rachmadi, 2003, Pembaharuan Hukum Lingkungan Nasional, PT Citra Aditya Bakti, Bandung.

Yasminingrum, 2017, Kebijakan Lingkungan Hidup dalam Konteks Good Governance, Jurnal Ilmiah Dunia Hukum, Vol. 13 No.1. 